\title{
Labour Relations at the Transition from Fordism to Postfordism, or: Why are an increasing number of «foreign foreigners» employed in the Swiss hotel and catering industry today?
}

\author{
Katrin Schneeberger, Paul Messerli, Berne'
}

\section{Introduction}

In the course of the globalisation of markets and the international competition between locations, analyses of regional economies as well as strategies of locational policies focus mainly on the entrepreneurial and regional capacity of innovation and competitiveness. As far as today's conditions of the capacity of innovation and competitiveness are concerned, economic geography mainly refers to the territorially orientated «new» innovation theories, which go back to the milieu theory by Aydalot (1985), the theory of flexible specialisation by PIORE \& SABel (1984), the Californian school by SCOTr (1988) and STORPER (1995) and the theory of competitiveness by PORTER (1990). All of them stress the importance of the regional environment, i.e. the so-called territorial embeddedness, for the improvement of the capacity of innovation of enterprises and regions. Moreover, all of them state the labour market to be simply one key factor of the regional environment. If the regional environment has skilled employees with specialist knowledge of specific industries, and employees who move up career chains in the regional labour market and work under flexible labour relations, advantages of competitiveness can be realised. In such work environments, highly qualified mobile foreign employees are also increasingly of interest (FREUND 1998). What is being asked for are not just generally more flexible labour markets but also the quicker availability of a highly qualified foreign labour force. Thus, it becomes clear that the above-mentioned theories all focus on one specific segment of the labour market: the one which is beneficial to the capacity of innovation and competitiveness.

In recent times, analyses of regional economies (BENKO 1996; OSSENBRÜGGE 1996) have increasingly referred to regulation theory (AgLieTTA 1979; LIPIETZ 1985; BOYER 1986) with the central theme being the current economic-structural change as a transition from Fordism to Postfordism. In regulation theory, the regional labour market is also a "primary topic» (DANIELZYK 1998: 414). This is because the transformation of the so-called wage relation and its regulation has a key function in stabilising economic accumulation (Du TERTRE 1995b: 323). But in contrast to the previously mentioned innovation theories, regulation theory assumes a critical perspective. By «critical» we mean an attitude that does not simply demand an adaptation of the labour force to the requirements of the capacity of innovation and competitiveness, but which deals with the question of what kind of labour relations are "produced» under the maxim of flexibilisation and what this implies for the relationship between domestic and foreign employees. It considers the whole spectrum of labour relations. A critical perspective not only focuses on the market where the winner gets everything but also simultaneously on its competitiveness, which creates a large number of losers (SENNETT 1998). It begs the question of who those «losers» are. Doreen Massey (1993), for example, exposes the innovative «Cambridge phenomenon", that is one of those flexible, specialised, embedded regions with economic growth, as a region comprising the new old male. According to her, the main point lies in the organisation of this (flexible) work, which requires employees who are not burdened with any housework or childcare. Ideally this means that these male employees have somebody who looks after them. Another issue that has not been greatly analysed, but is no less subject to current changes than the gender relationship, is the relationship between different ethnicities, i.e. between domestic and foreign labour forces (BAGguley et al. 1990:26).

Tourism - incorporating the hotel and catering industry as its main representative (KELLER \& KoCH 1997: 13) - is an important industry, quantitatively as well as qualitatively. Quantitatively, it ranks as one of the most important employers in highly developed economies (Keller 1996), being a traditional area of employment for foreign employees as well as for domestic ones (WALDINGER 1992; KING 1995). Because of its economic growth, it is even predicted to become the most important industry in the near future (KocH 1998: 22). Qualitatively, tourism and the hotel and catering industry are of interest because they are regarded as precursors of new labour patterns. It is precisely in the labour market that the hotel and catering industry tends towards flexibilisation at an earlier point than other industries (BAGGULEY 1990: 743; URRY 1990).

\footnotetext{
1) This paper is a revised version of Schneeberger, K. \& P. Messerli (2001): Das Lohnverhältnis und seine duale Regulation. Gewinner und Verlierer der Flexibilisierung auf dem Arbeitsmarkt der Schweizer Hotellerie und Gastronomie. In: Geographische Zeitschrift 89, Heft 1:52-68.
} 
As Switzerland is a country with high costs of living and high salaries, the conditions of the capacity of innovation and competitiveness represent a particular challenge. Just as important are the efforts of reducing barriers that stand in the way of the flexibilisation of labour relations. Therefore the call for a flexibilisation of labour markets and for a new foreign labour policy is strong. What is being asked for is a system of admission for highly qualified employees and thus the abandonment of the so-called «Gastarbeitersystem» that promotes the immigration of unqualified employees (HAUG 1998; RoHNER 1999). Foreign employees in particular were attributed the role of the epreventers of structural change» (SCHWARZ 1988).

In the following article, therefore, we are going to discuss the trend towards flexibilisation of labour relations with particular reference to the relationship between domestic and foreign employees by using the example of the Swiss hotel and catering industry. As a mature but no longer growing tourist destination, the Swiss hotel and catering industry is particularly challenged by global competition and the conditions of innovation and competitiveness (BIEGER 1998; BIEGER \& FREY 1998). It follows that the flexibilisation and differentiation of labour relations should be equally advanced. Mainly because of the lack of incentives for the Swiss to work in the Swiss tourist industry, a «Gastarbeiter» problem has evolved (Keller 1996; AePPLI 2001), which has manifested itself in an ethnic stratification of the labour market through an imported labour force.

We are going to analyse the transition towards flexibilisation of labour relations by basing our arguments strictly on regulation theory, i.e. by employing the categories of this approach. In doing so, we will add a «critical perspective» to the «innovation and competitiveness»-oriented debate about the labour market. By focusing particularly on the relationship between domestic and foreign employees, the gap of conceptualisation, for which the regulation theory has been criticised (BAKSHI et al. 1995), will be bridged i.e. the neglected race issue in relation to flexibility. Moreover, the scope of the categories of the regulation theory and especially the rigid periodisation in Fordist and Postfordist characteristics will be examined. By concentrating on the hotel and catering industry, the demand for an extension of regulationist analysis to the service sector can be met (DU TeRTRE 1995 a, b). Finally, by using the Swiss example, the FordismPostfordism debate dealing with labour markets and migration, such as it is represented by BIELING's (1993) work for Germany and Parenreiter's work (1994) for Austria, can be completed with a national «development path» (BOYER 1992), which has been largely neglected until now.
The paper is structured as follows: in the second section we are going to discuss the perspective presented by the regulation theory. In the succeeding sections, we will move on to an empirical discussion of the Swiss hotel and catering industry - the third section focusing on Fordism and the fourth section on Postfordism. The discussion is based on 50 qualitative interviews with key representatives of the hotel and catering industry, employers as well as domestic and foreign employees. The interviews have been carried out and interpreted according to the method of structuring content analysis (MAYRING 1993; cf. also SchneEberger 2000). The findings and conclusions will be presented in the final section.

\section{The perspective of regulation theory}

At the centre of the French regulation theory (AGLIETTA 1979; LipieTz 1985; Boyer 1986), which is also known as the theory of the transition from Fordism to Postfordism, are the «social relations» (LipIeTz 1985) or «institutional forms» (BOYER 1986) between social actors. With the inter-company relation, the wage relation, the money relation, the relation to the state and the incorporation into the world economy, five social relations are under discussion which all have a contradictory and conflicting character. In the present case, the wage relation, meaning the conflicting relationship between capital and labour, or employers and employees respectively, is of particular interest. According to regulation theory, it consists of the following dimensions: direct and indirect wages, technical and social work organisation as well as mobility and the employees' loyalty to the company (BOYER 1995).

Because of the conflicting character of social relations, regulation, i.e. a set of rules and norms, is needed in order to bring about a social compromise. Only the regulation of these relations guarantees economic accumulation. This division into a regime of accumulation and a mode of regulation is based on the idea that the capitalist accumulation process must be secured by a regulatory system. The latter allows for reproduction in spite of the conflicting character of social relations. Phases of stable reproduction form the so-called development models, i.e. Fordism and Postfordism.

Although regulation theory adopts a critical perspective (cf. section 1), it has been criticised for its onesided focus on class analysis while ignoring race issues (BAKSHI et al. 1995). This «blind spot» is important for the understanding of the Fordist development model, because especially in Western Europe, economic growth would not have been possible without the recruitment of the so-called "Gastarbeiter" (SASSEN 1996). As a result of the "racialised character» of Fordist regulation (BAKSHI et al. 1995), these «Gast- 
arbeiter» moreover belong to the losers on the Fordist labour market. With a view to the increasing flexibilisation of labour relations and to the question of the winners and losers on the labour market, the question of how to respond to this criticism must be addressed. Giving race issues their place within the wage relation and its regulation means to expand the meaning of the wage relation and its regulation: the wage relation has to be understood as doubly conflicting and therefore focused on two social compromises (SCHNEEBERGER 2000; Schneeberger \& Messerli 2001). Besides the class compromise, which results from the regulation of the conflict between capital and labour, it also includes the compromise resulting from the conflict between ethnicities and/or nationalities. In other words, the wage relation needs a dual regulation system in order to bring its double conflict to a social compromise.

\section{The Swiss hotel and catering industry in Fordism}

\subsection{Fordist wage relations}

The Swiss hotel and catering industry in the 1970s employed the «skilled manual workers» and «unskilled manual workers».

The «skilled manual worker» completed an apprenticeship as a cook or waiter, which guaranteed a solid technical know-how. Because of the high standard of training, the Swiss hotel and catering industry was/is said to be one of the best of its kind. The work of the «skilled manual worker» was organised in a strictly hierarchical fashion. A cook, for example, worked in hierarchically ascending order as a «commis», «chef de partie», «sous chef» or «chef de cuisine». The work was divided functionally in a similarly rigid way that can best be demonstrated with the «chef de partie» and his or her «parties» (areas of responsibility): «rôtisseur», "patissier», "gardemanger», "entremetier» or «saucier». All these different functional tasks had to be covered during a standard career. The «skilled manual worker» belonged to a profession, which could involve union membership.

«Skilled manual workers» were of domestic as well as foreign nationality. As a seasonal worker or an annual permit resident, the foreign «skilled manual worker» chose to gain professional experience in Switzerland because of the good reputation of the Swiss hotel and catering industry.

The «unskilled manual worker» comprised workers with compulsory school education but without any apprenticeship and experience in the hotel and catering industry. In the hotel-restaurant they performed given tasks and had limited responsibility. These were tasks for which no clear professional training existed such as a washer, chambermaid or a storeman. Further, the «unskilled manual worker» assisted the «skilled manual worker» along clear divisions of function: for example he helped the «skilled manual worker» responsible for the fish to clean them i.e. to remove the scales. With longer employment duration an internal change of job was possible. A job change was not usually career or goal orientated and could also entail a change between departments, for example a change from the kitchen to the rooms.

«Unskilled manual workers» were exclusively of foreign nationality. They had the status of seasonal workers or annual permit residents. Their motivation to work in Switzerland was to earn money.

Figure 1a depicts the Fordist wage relation:The «skilled manual worker» and the «unskilled manual worker» are characteristic for Fordism inasmuch as they represent the dual segmentation of the labour market in general (BOYER 1995: 112), as well as of the tourist labour market in particular (SHaw \& Williams 1994). The segmentation occurs in a primary and secondary segment of the labour market. The primary segment is characterised by hierarchical work organisation, functional work division, professional membership and fixed career patterns and career chains as represented by the «skilled manual worker». The secondary segment, on the other hand, is characterised by functional work division and a lack of career opportunities in occasional horizontal job chains as represented by the «unskilled manual worker». Moreover, the «unskilled manual worker» is typically Fordist inasmuch as it is restricted to the foreign labour force. It stands for a tourist labour market that is segmented ethnically as well as along the category of nationality (SHAw \& WILLIAMS 1994: 138; AEPPLI 2001).

\subsection{Fordist regulation}

The wage relation of the "skilled manual worker» and of the «unskilled manual worker» are, on the one hand, contractually fixed within the global labour contract and, on the other hand - for the foreign labour force - , with the so-called foreign labour force quota.

The global labour contract, which came into effect in 1974, corresponds to the "Swiss social partnership». «Social partnership» means that the employers' associations and the employees' union regulate domestic and foreign labour relations together. «Swiss» denotes the role of the state, which declares the contract generally binding for the whole Swiss hotel and catering industry (Du Pasquier \& Marco 1991). The global labour contract remained valid until 1996.

The foreign labour force quota, which came into effect in 1970 in the wake of immigration policy regulations on 
(a) Wage relation

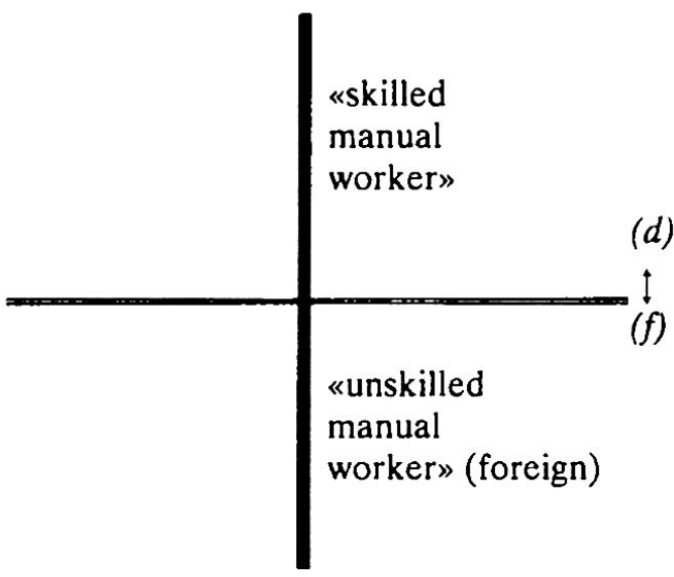

(c) $<->(l)$ (b) Regulation

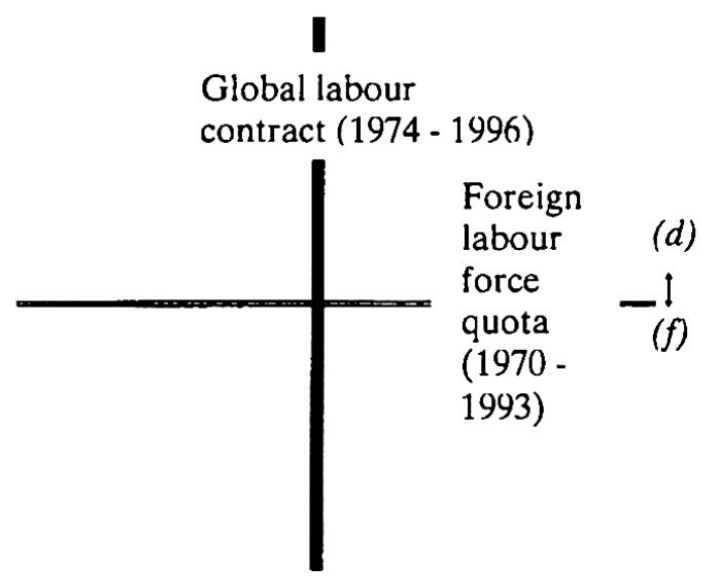

(c) $<->(l)$

Key
Dominant conflict line between capital $(c)$ and labour $(l)$ force

Fig. 1: The wage relation (a) and its regulation (b) in Fordism

Das Lohnverhältnis (a) und seine Regulation (b) im Fordismus

Le rapport salarial au fordisme (a) et sa régulation (b)

Diagram by the authors

admissions, shows the «racialised character» (BAKSHI et al. 1995) of Fordist regulation. Since the foreign labour force quota limits the stay of the foreign labour force both temporally and quantitatively, the domestic and the foreign labour force are subject to unequal institutional treatment. The regulations remained in effect until 1993, the year in which the Swiss government was charged with the implementation of a new migration policy (immigration and asylum policy).

The «Swiss social partnership» and the «racialised character» of regulation as shown in Figure $1 \mathrm{~b}$ are characteristic of Fordism in two ways: on the one hand, the «social partnership» represents the so-called class compromise. This is the result of the class struggle dominating Fordism along the conflict line between capital and labour. It leads to the labour relations and working conditions that are dominant in the primary segment of the labour market.

On the other hand, the racialised character of regulation is characteristic of Fordism inasmuch as the capitalist economy has to operate on an intrinsic uncertainty that is due to cyclical fluctuation. The functioning of the economy depends on whether it is able to offset this uncertainty and to level the contradictions in time and space (Graham 1991), for instance with a flexible labour pool which can be activated during boom periods at short notice and dismissed during recessions at just as short notice. In this sense, the foreign labour force quota regulates the conflict between nationalities by discriminating against the foreign labour force. It produces the working conditions that are dominant in the secondary segment of the labour market.

\section{The Swiss hotel and catering industry in Postfordism}

\subsection{Postfordist wage relations}

At the beginning of the $21^{\text {st }}$ century, the following labour force is employed in the Swiss hotel and catering industry:

«Middle managers» distinguish themselves by a democratic right of participation within the firm in order to profit from their competence on the one hand and to increase their motivation on the other hand. They have 
completed an apprenticeship and several years of professional experience in the hotel and catering industry. Because their technical know-how has become insufficient, they have acquired additional qualifications, especially in communication and foreign languages. They facilitate contact with the customers, which is of crucial importance for services. As a «middle manager» one belongs to a team, even to a «family». The functional division of labour is replaced by functional flexibility. The «middle manager» is no longer employed for only one task but for at least two.

The «middle manager» can be recruited from the domestic as well as from the foreign labour force. Foreign employees have had their residence permits changed to annual or permanent residence permits because they have already been in Switzerland for a long time.

The wage relation of the «temporary worker» describes employees who do not have an apprenticeship or experience in the hotel and catering industry. The «temporary worker» performs tasks which up to now required a specific apprenticeship in the industry, but which have become standardised in the wake of mechanisation and externalisation of services (convenience food, standardised food production systems). As a student, for example, he or she has a higher education, which guarantees a quick grasp of the tasks involved. For the headwaiter, who is ultimately responsible, it is no problem that he or she does not have a specific education in the industry: «Subject-specific know-how, for example in a service industry, that is not so important for me. A waitress can pour sauce over your head... If she does it well, and is friendly, it's hardly a problem anymore today.» The pay varies according to the total numbers of hours worked and is cashed up daily after work as a fixed hourly wage. He or she is available on a temporary basis. After a period of work, he or she is not bound to anything anymore. The «temporary worker» works on instruction. Being «temporary workers», they often do not build up a feeling of belonging or loyalty to the firm and in many cases do not know their colleagues. He or she does not have professional perspectives within the firm or the industry. Mobility is also high among these workers.

The «temporary worker» includes domestic as well as foreign employees. Foreign temporary workers have a residence permit.

The wage relation of the «new professional» denotes a type that does not have an apprenticeship in the hotel and catering industry, but instead a qualification from another industry such as the performing arts or computer industries. An apprenticeship in the hotel and catering industry is not required because the function of the hotel-restaurant has been redefined. The «new professional» simply uses his or her acquired skills in a new environment. The «new professional» is employed for specific projects. Loyalty to the firm is therefore relatively low. As a co-worker, who is «mainly employed in a related industry», he or she is not bound by the global labour contract (in accordance with Article 2 «non-applicability» of the global labour contract).

Domestic as well as foreign employees make up the «new professional» workforce. Foreign employees have a residence permit.

The «asylum seeker» works as a washer or cleaner and carries out unqualified tasks like the «unskilled manual worker», tasks which have become even more monotonous as a result of mechanisation. An «unskilled manual worker» in Postfordism acknowledges his or her relatively superior position, because an «asylum seeker» is now placed under his or her supervision: «I have a Tamil.» The «asylum seeker» is part of a comparatively cheap labour force: «... but what we have noticeably more of in areas where the population is growing, are asylum seekers... And their wages are extremely low.» The employer has to pay the minimum wage according to the global labour contract but charities pay for accommodation and insurance if the wage is insufficient for the family who fled with the employee. In the case of a seasonal worker, that benefit cannot be relied upon.

The «asylum seeker» is exclusively of foreign nationality. He has the status of an asylum seeker.

Alongside the «middle manager», the «temporary worker», the «new professional» and the "asylum seeker», the wage relations of the Fordist «skilled manual worker» as well as of the «unskilled manual worker» continue to exist (cf. section 3.1). They still maintain their traditional functions.

If they are of foreign nationality, they may have changed their residence permit into an annual or permanent permit in the meantime.

Figure 2a depicts the Postfordist wage relations: The broad range is characteristic for Postfordism as it stands for functional flexibility, as shown by the «middle manager» for example, and for numerical flexibility, as shown by the «temporary worker» (LEBORGNE \& LIPIETZ 1991). Flexibility is necessary in order to meet the differentiated and individualised conditions of production and consumption. The fact that five out of the six wage relations are covered by the domestic as well as the foreign labour force points to a decreasing ethnic segmentation of the tourist labour market in Postford- 
(a) Wage relation

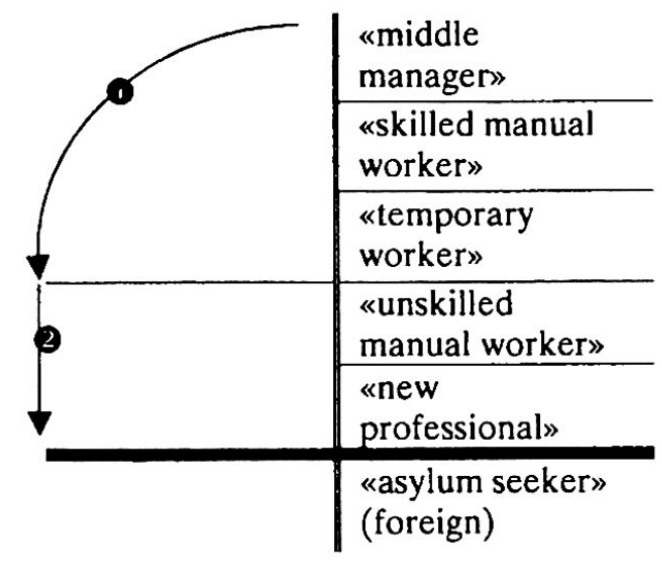

(c) $<->(l)$ (b) Regulation

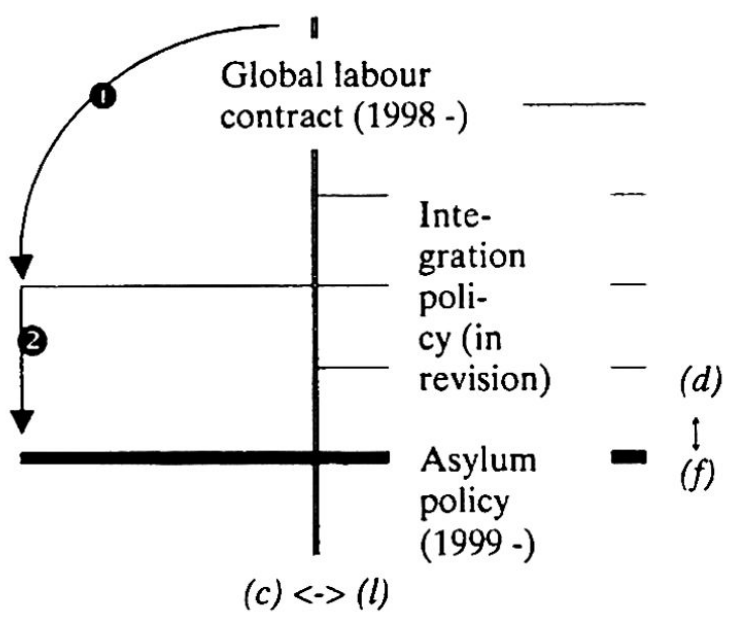

Key

Dominant conflict line between domestic $(d)$ and foreign $(f)$ labour force

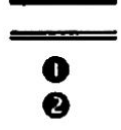

Subordinate conflict line between capital (c) and labour (l)

Shifting of the dominant conflict line

Lowering of the ethnic stratification

Fig. 2: The wage relation (a) and its regulation (b) in Postfordism

Das Lohnverhältnis (a) und seine Regulation (b) im Nachfordismus

Le rapport salarial au postfordisme (a) et sa régulation (b)

Diagram by the authors

ism. At the same time, a new, hierarchically lower, ethnic stratum arises, represented by the «asylum seeker».

\subsection{Postfordist regulation}

The regulation which governs the wage relations of the «middle manager», the «temporary worker», the «new professional», the «asylum seeker» as well as the Fordist «skilled manual worker» and the Fordist «unskilled manual worker» is covered by a new global labour contract and, in the case of the foreign labour force, the new migration policy (immigration and asylum policy).

The new global labour contract, which has been in effect since 1998, again stands for the «Swiss social partnership»; once again, the «social partnership» denotes the regulation that is negotiated between employers' associations and the employees' union. The state declares it to be a generally binding contract. Compared to its Fordist predecessor, it is more liberal and flexible.

The discussion of immigration policies is now domi- nated by a policy of integration. Addressed to all foreign employees except for asylum seekers, it represents an «informal regulation»: informal means that in contrast to the "social partnership», it only has advisory status. Proposals made in this context, which were aimed at the equality of foreigners on the labour market, resulted in a bill for an integration article in the federal law on admissions and the residence of foreigners. It allows for financial support for the integration of foreigners to be paid for by the confederation. Discussions on migration policy, however, are dominated by asylum policies: by introducing the category of «people in need of protection», the law of asylum, which was totally revised by the summer of 1999 , contains an improvement for one category of asylum seekers. But since the urgent federal decision about measures against uncooperative asylum seekers is of a restrictive nature and therefore produces new institutional differences, the regulation must again be criticised for its racialised character.

This regulation, as depicted in Figure 2b, is characteristic for Postfordism in different ways: The «Swiss social 
partnership» represents again the «class compromise», as it is also discussed in Postfordism (TrCKell \& PeCK 1992:194).

The «informal regulation» is directed at a non-discriminating compromise between nationalities, since there is a large degree of agreement on the conflict lines in Postfordism shifting away from class towards ethnicity (e.g. WICKER 1998: 32). In Fordism, the class compromise that followed the class struggle resulted in secure working conditions. By analogy, it is now imaginable that a compromise between ethnicities or nationalities which does not discriminate against the foreign labour force could arise as a result of an ethnical conflict in Postfordism: «The process of ... racial domination inherent in the Fordist mode of social regulation prompted responses from ... those defined as ethnic minorities» (BAKSHI et al. 1995: 1552). At the same time, Switzerland's asylum policy demonstrates that through the creation of a compromise between nationalities, the racialised character of regulation is institutionalised anew.

\section{Findings and conclusions}

The analysis of wage relations and their regulation based on regulation theory, which has been enlarged by the ethnic dimension, shows the following picture of the flexibilisation in the labour market of the Swiss hotel and catering industry:

Firstly, the diversity of labour relations has increased from two to six types. With the «skilled manual worker» and the «unskilled manual worker», the existence of Fordist rigid labour characteristics such as hierarchical labour organisation, functional work division and fixed career patterns in coexistence with Postfordist flexible labour relations has been proved. This particular industry is regarded as a precursor of flexible labour patterns and therefore as simply the Postfordist industry (URRY 1990). The fact that the «unskilled manual worker» and the «asylum seeker» coexist on the labour market confirms KuSTER \& CAVELTI's opinion (2000: 50) that employees with the status of asylum seekers have a complementary and not substituting function in the Swiss labour market.

Secondly, linked to the diversification of labour relations, the relationship between the domestic and foreign labour force is developing in a contradictory way: on the one hand, this diversification blurs the boundary between the foreign and domestic labour force and therefore decreases the segmentation along the category "nationality». With the exception of one type, domestic as well as foreign employees occupy all types of labour relations. As foreign employees are thus integrated into the transformation of production on all levels, their alleged role as "preventers of structural change» (Schwarz 1988; ÄPPLI 2001) is questionable. This observation points to a non-discriminating compromise between nationalities. On the other hand, however, a new, lower stratum represented by the «asylum seeker» has come into being, which is restricted to foreign employees and is therefore an ethnic segmentation. Compared to its Fordist predecessor, this segmentation is more accentuated, rendering it qualitatively more precarious (cf. Figure 2).

It follows from this contradictory development that the categories «domestic» and «foreign» themselves have become insufficient. Instead, there seem to be «real» domestics and «real» foreigners and, in between these two categories, a large group of foreigners who have a foreign passport, but as «residents» are functionally equated with the domestics in the labour market. One of the interviewed employers says:

«(...) if somebody has already been in Switzerland for 10 years and doesn't have a Swiss passport, I would almost consider him to be Swiss".

This group is contrasted by the group of the «real» foreigners, the so-called «foreign foreigners»:

"We increasingly have (foreign foreigners, those who really have come to Switzerland for the first time and don't speak a single word of German. When you need a washer you get hundreds of applications from Sri Lankans to Bosnians, Serbs or Tamils, and where do they all come from, from Africa, (...) tons of people who apply to work here».

They are foreigners according to their nationality as well as to their function in the labour market.

Thirdly, the analysis of labour relations, which has been expanded by the relationship between foreign and domestic labour, i.e. the removal of the «blind spot» of regulation theory (BAKSHI et al. 1995), has led to an extended notion of regulation: this notion focuses on the regulation of the conflict between capital and labour as well as the conflict between nationalities or ethnicities. This expansion to a dual regulation system is necessary for two reasons in order to understand Fordism and Postfordism: on the one hand, a stratification which refers to the category of nationality or ethnicity is an integral part of both development models. On the other hand, the shift of the dominating conflict from the line between capital and labour to the one between nationalities or ethnicities is a hallmark of the transition from Fordism to Postfordism.

Fourthly, the contradictory development of the relationship between the domestic and foreign labour force has its counterpart on the institutional or regulative level in the modification of the dual regulation system: 
With regard to the conflict line between capital and labour, the Swiss «development path» continues to be characterised by a corporatist (Fordist) regulation, i.e. one influenced by the state, unions and employers' associations. The demand for the diversification of labour relations is met by a more flexible global employment contract.

The regulation of the conflict along the line between nationalities or ethnicities, within the scope of the new migration policy, gives rise to the supposition that integration efforts are only obtainable at the cost of other kinds of discrimination. In other words, the shifting of importance from a policy of admissions to a policy of integration coincides with an increasingly restrictive asylum policy. This new, institutionally produced ethnical stratification supports the conclusion that asylum seekers represent a new possibility for externalising the uncertainty inherent in capitalism.

Fifthly, the analysis of labour relations from a «critical» perspective based on regulation theory has identified characteristics in the labour market such as differentiation and accentuated lower ethnic stratification, which would not have emerged by using one of the new innovation theories put forward at the beginning. In other words, the discussion would have been much more detailed, but very one-sided, focusing on the «middle manager» as winner but not on the «asylum seeker» as loser of the socio-economic transition. Especially in economic geography, a perspective that focuses on the whole spectrum of labour relations - we called it a «critical perspective» at the beginning - is in our opinion more necessary than ever before. At a time where concepts such as the aforementioned regional embeddedness gain popularity, concepts which foreground the «bed» in «em-bed-dedness» in their title give the impression of safety and warmth (SAYER 2001). But this new capitalism, often called «softer» capitalism (in order to contrast it with its predecessor), also produces its losers.

Finally, regulation theory has its limits as a theoretical basis for labour market analysis inasmuch as the strict periodisation into Fordism and Postfordism cannot be maintained. Instead, the coexistence of Fordist/ rigid and Postfordist/flexible characteristics as identified for tourism by RITZER \& LISKA (1997) is confirmed.

The categories and dimensions offered by regulation theory reach their limits where current problems centre around an insufficient recognition rather than an unequal distribution - in other words, where a focal shift from economic-material questions of distribution, the so-called "politics of distribution», to culturalimmaterial questions of recognition and identity, the so-called «politics of recognition», can be observed. This is also the case in the labour market of the Swiss hotel and catering industry. The categories based on regulation theory, which has been expanded by the ethnic dimension, can be applied to the ethnic segmentation in the sense of an economic discrimination against the «unskilled manual worker» in Fordism and against the «asylum seeker» in Postfordism. But the same categories are insufficient when analysing the problems mentioned by foreigners of all the other types of labour relations. In answer to the question of what he is worried about in his current job situation, a Portuguese waiter, for example, a Postfordist «skilled manual worker», who has been working in Switzerland for eight years, does not complain about the low salary or the irregular working hours. Instead, he says the following:

«I look at myself in the mirror and I think, Manuel, what did you look like eight years ago and what do you look like now after eight years in Switzerland? And I know that if I stay here for a long time I'll change slowly. It's a pity because I'll totally forget my culture. But I also can't stay one hundred percent anymore who I used to be. And I also can't become a real Swiss man. In fact it's becoming a bit complicated. My own identity, who am I, where am I ... It's difficult.»

It is precisely at this point that the discussion which has recently become popular under the title of the «cultural turn» (see LEE \& WiLls 1997; RAY \& SAYER 1999; STORPER 2001) promises new insights. Nevertheless, in spite of the "cultural turn", analyses based on regulation theory, which focus on questions of economicmaterial distribution, cannot be discarded - a proof of which we believe to have provided by identifying the "asylum seekers» as the emerging losers in the process of flexibilisation.

\section{Acknowledgments}

The author is indebted to the Swiss National Science Foundation for their financial support of her stay abroad at the Sociology Department of Lancaster University (UK) within a grant scheme for «prospective researchers».

\section{Literature cited}

Aeppli, R. (2001): Volkswirtschaftliche Analyse der Probleme des Arbeitsmarktes im schweizerischen Gastgewerbe. $-=$ Seco Publikation, Standortförderung Nr. 4 (07.2001), Bern.

Aglietta, M. (1979): A Theory of Capitalist Regulation. The US experience. - London: New Left Books (NLB). Aydalot, P. (1985): Milieux innovateurs en Europe. Paris: Selbstverlag Groupe de recherche européen sur les milieux innovateurs (GREMI).

BAgGuley, P. (1990): Gender and Labour Flexibility in 
Hotel and Catering. - In: The service industries journal 10/4: 737-747.

Bagguley, P., Mark-Lawson, J., Shapiro, D., Urry, J., Walby S. \& A. Warde (1990): Restructuring: Place, class and gender. - London: Sage.

Bakshi, P., Goodwin, M., Painter, J. \& A. Southern (1995): Gender, race and class in the local welfare state: moving beyond regulation theory in analysing the transition from Fordism. - In: Environment and Planning A 27/10: 1539-54.

BENKo, G. (1996): Wirtschaftsgeographie und Regulationstheorie - aus französischer Sicht. - In: Geographische Zeitschrift 84/3,4: 187-204.

BIEGER, T. (1998): Von der Gästefreundlichkeit zum professionellen Dienstleistungsprozess - die Tourismuswirtschaft vor einem Paradigma. - = Jahrbuch der Schweizerischen Tourismuswirtschaft 1997/98, St. Gallen: 1-32.

Bieger, T. \& M. Frey (1998): Lage und Zukunftsperspektiven der Schweizer Hotellerie. - In: Revue de Tourisme 1:23-36.

Bieling, H.-J. (1993): Nationalstaat und Migration im «Postfordismus» - Gewerkschaften vor der Zerreissprobe. - Unveröffentlichte Studie Nr. 2 der Forschungsgruppe Europäische Gemeinschaften (FEG), Marburg. BOYER, R. (1986): La Théorie de la régulation. Une analyse critique. - Paris: Edition la découverte.

BOYER, R. (1992): Neue Richtungen von Managementpraktiken und Arbeitsorganisation. Allgemeine Prinzipien und nationale Entwicklungspfade. - In: Demirovic, A., Krebs, H.-P. \& T. Sablowski (eds): Hegemonie und Staat. Kapitalistische Regulation als Projekt und Prozess. - Münster: Verlag Westfälisches Dampfboot: 55-103.

BOYER, R. (1995): Vingt ans de recherches sur le rapport salarial: un bilan succinct. - In: BOYER, R. \& Y. Saillard (eds): Théorie de la régulation. L'état des savoirs. - Paris: La découverte: 106-114.

DanielzyK, R. (1998): Zur Neuorientierung der Regionalforschung. - = Wahrnehmungsgeografische Studien zur Regionalentwicklung 17, Oldenburg.

Du Pasquier, J.-N. \& D. Marco (1991): Régulation fordiste et post-fordiste en Suisse depuis 1937. Matériaux pour une approche (non publié), Unité pour l'étude de la régulation, Université de Genève.

Du Tertre, C. (1995a): La dimension sectorielle de la régulation. - In: BOyer, R. \& Y. Saillard (eds) : Théorie de la régulation. L'état des savoirs. - Paris: La découverte: 313-322.

Du Tertre, C. (1995b): Une approche sectorielle du travail. - In: Boyer, R. \& Y. SAILLARD (eds) : Théorie de la régulation. L'état des savoirs. - Paris: La découverte: 323-331.

Freund, B. (1998): Frankfurt am Main und der Frankfurter Raum als Ziel qualifizierter Migranten. - In: Zeitschrift für Wirtschaftsgeographie 42/2: 57-81.

Graham, J. (1991): Fordism/Post-Fordism, Marxism/
Post-Marxism: The Second Cultural Divide? - In: Rethinking MARXISM 4/1:39-58.

HAUG, W. (1998): Die Schweiz als Einwanderungsland. - In: Prodolliet, S. (ed.): Blickwechsel. Die multikulturelle Schweiz an der Schwelle zum 21. Jahrhundert. - Luzern: Caritas Verlag: 62-79.

Keller, P. (1996): Der touristische Arbeitsmarkt in hochentwickelten Volkswirtschaften - eine Möglichkeit zur Schaffung von Arbeitsplätzen? - = Jahrbuch der Schweizerischen Tourismuswirtschaft 1995/96, St. Gallen: 63-73.

Keller, P. \& K. Koch (1997): Neue Tourismuspolitik. Wettbewerb, Zusammenarbeit und Innovation. - In: Die Volkswirtschaft - Magazin für WirtschaftsPolitik 8: 12-17.

KING, R. (1995): Tourism, Labour and International Migration. - In: Montanari, A. \& A.M. Willliams: European Tourism. Regions, Spaces and Restructuring. - Chichester: Wiley: 177-190.

Koch, K. (1998): Der Schweizer Tourismus auf dem Weltmarkt - neue Entwicklungen im internationalen Tourismus. - In: Die Volkswirtschaft - Magazin für WirtschaftsPolitik 10: 22-25.

Kuster, J. \& G. CAVELTI (2000): Rekrutierung ausländischer Arbeitskräfte. Bedeutung ausländer- und asylrechtlicher Bestimmungen. - Seco Publikationen Arbeitsmarktpolitik 2 (2.2000), Bern.

LEBORGNE, D. \& A. LipIETZ (1991): Two social strategies in the production of new industrial spaces. - In: BENKO, G. \& M. DUNFord: Industrial change and regional development: the transformation of new industrial spaces. - London: Belhaven Press: 27-50.

LEe, R. \& J.Wills (ed.) (1997): Geographies of Economies. - London: Arnold.

LipietZ, A. (1985): Réflexions autour d'une fable. Pour un statut marxiste des concepts de régulation et d'accumulation. - CEPREMAP 8530, Paris (non publié).

Massey, D. (1993): Raum, Ort und Geschlecht, Feministische Kritik geographischer Konzepte. - In: BüHLER, E. \& A. Scheller (eds): Ortssuche. Zur Geographie der Geschlechterdifferenz. - Zürich: eFeF-Verlag: 109-122. MaYring, P. (1993): Qualitative Inhaltsanalyse, Grundlagen und Techniken. - Weinheim: Deutscher Studien Verlag.

OSSENBRÜGge, J. (1996): Regulationstheorie und Geographie - Einführung in das Themenheft. - In: Zeitschrift für Wirtschaftsgeographie 40/1, 2: 2-5.

Parnreiter, C. (1994): Migration und AusländerInnenbeschäftigung in der Weltwirtschaftskrise.-Wien: Promedia.

Piore, M. \& C. Sabel (1984): The second industrial divide: possibilities for prosperity. - New York: Basic Books.

Porter, M.E. (1990): The competitive advantage of nations. - Basingstoke: Mcmillan.

RAY, L. \& A. SAYER (ed.) (1999): Culture and Economy After the Cultural Turn. - London: Sage. 
Ritzer, G. \& A. LiSKA (1997): «Mc Disneyization〉 and 〈post-tourism»: Complementary perspectives on contemporary tourism. - In: ROJEK, C. \& J. URRY (ed.): Touring Cultures. Transformations of travel and theory. - London: 96-109.

RoHNER, K. (1999): Schweizerische Ausländerpolitik im Wandel. - In: Die Volkswirtschaft - Magazin für WirtschaftsPolitik 3: 18-24.

SASSEN, S. (1996): Migranten, Siedler, Flüchtlinge. Von der Massenauswanderung zur Festung Europa.Frankfurt am Main: Fischer.

SAYER, A. (2001): For a Critical Cultural Political Economy. - In: Antipode. A Radical Journal of Geography, 33/4: 687-708.

SCHNEeberger, K. (2000): Vom fordistisch-nationalstaatlichen Klassenkompromiss zu nachfordistischregionalen Kompromissen zwischen Nationalitäten? - Unveröffentlichte Dissertation an der Universität Bern.

Schneeberger, K. \& P. Messerli (2001): Das Lohnverhältnis und seine duale Regulation. Gewinner und Verlierer der Flexibilisierung auf dem Arbeitsmarkt der Schweizer Hotellerie und Gastronomie. - In: Geographische Zeitschrit 89, Heft 1: 52-68.

SCHWARZ, H. (1988): Volkswirtschaftliche Wirkung der Ausländerbeschäftigung in der Schweiz. - Gruesch: Verlag Ruegger.

ScotT, A. (1988): New Industrial Space: Flexible Production Organization and Regional Development in North America and Western Europe. - London.

SENNETT, R. (1998): The corrosion of character: the personal consequences of work in the new capitalism. - New York: W.W. Norten.

Shaw, G. \& A.M. Williams (1994): Critical Issues in Tourism. A Geographical Perspective. - Oxford: Blackwell.

STORPER, M. (1995): The resurgence of regional economies, ten years later: the region as a nexus of untraded interdependencies. - In: European Urban and Regional Studies 2: 191-221.

Storper, M. (2001): The Poverty of Radical Theory Today: From the False Promises of Marxism to the Mirage of the Cultural Turn. - In: International Journal of Urban and Regional Research 25/1: 155-179.

Trckell, A. \& J.A. PeCK (1992): Accumulation, regulation and the geographies of post-Fordism: missing links in regulationist research. - In: Progress in Human Geography 16/2: 190-218.

URRY, J. (1990): The Tourist Gaze. Leisure and Travel in Contemporary Societies. - London: Sage.

WALDINGER, R. (1992): Taking Care of the Guests: The Impact of Immigrants on Services - An Industry Case Study. - In: International Journal of urban and regional Research 16/1: 97-113.

WiCKER, H.-R. (1998): Zu Rasse, Kultur, Nation und ethnischer Identität. Oder zur Frage: Wer gehört dazu und wer nicht? - In: Prodolliet, S. (ed.): Blickwech- sel. Die multikulturelle Schweiz an der Schwelle zum 21. Jahrhundert. - Luzern: Caritas-Verlag: 21-36.

\section{Summary: Labour Relations at the Transition from \\ Fordism to Postfordism, or: Why are an increasing number of «foreign foreigners» employed in the Swiss hotel and catering industry today?}

In the present paper, we discuss a key factor in the entrepreneurial and regional capacity of innovation and competitiveness. By basing our arguments on regulation theory, we consider changes in domestic and foreign wage relations and their regulation as an expression and a reflection of flexible accumulation. In doing so, the dominant discussion of a labour market orientated towards innovation and competitiveness is given a critical dimension that focuses on the winners of the modernisation process as well as on possible losers of the flexibilisation.

We analyse the trend by using the hotel and catering industry as an example of an industry which assumes a pioneering role as far as the flexibilisation of the labour market is concerned. The Swiss example represents a national «development path», which is greatly challenged by the new conditions of competitiveness, giving rise to a strong call for a reduction in barriers that stand in the way of flexibilisation.

The empirical discussion is the result of qualitative interviews. It shows that the changes are characterised firstly by an increasing diversity of labour relations and secondly by an accentuated lower ethnic stratification of the labour market. Thirdly, the increasing diversity and the ethnic stratification are projected on the regulative level. Fourthly, the analysis leads to an expanded notion of regulation, which not only focuses on the conflict line between capital and labour, but also on the conflict line between ethnicities or nationalities (the dual regulation system). Finally, as a coexistence of Fordist and Postfordist labour relations is apparent, the impact of regulation theory is critically examined.

Zusammenfassung: Arbeitsverhältnisse am Übergang vom Fordismus zum Nachfordismus, oder: Warum werden heute in der Schweizer Hotellerie und Gastronomie vermehrt ausländisch wirkende Ausländer beschäftigt?

Im vorliegenden Artikel diskutieren wir einen Schlüsselfaktor der betrieblichen und regionalen Innovations- und Wettbewerbsfähigkeit. Aus einer regulationstheoretischen Perspektive wird nach dem Wandel des (in- und ausländischen) Lohnverhältnisses und dessen Regulation als Ausdruck und Abbild flexibler Akkumulation gefragt. Damit stellen wir der wettbewerbsund innovationsorientierten Diskussion des Arbeits- 
marktes insofern eine kritische Perspektive gegenüber, als sie sowohl auf die Modernisierungsgewinner, als auch auf mögliche Verlierer und Verliererinnen der Flexibilisierung fokussiert.

Die Diskussion führen wir in der Hotellerie und Gastronomie exemplarisch in jener Branche, welche bezüglich der arbeitsmarktlichen Flexibilisierung eine Pionierrolle einnimmt. Das Beispiel der Schweiz stellt einen «nationalen Entwicklungspfad» dar, der durch die neuen Wettbewerbsbedingungen besonders herausgefordert ist. Deshalb erklingt der Ruf nach dem Abbau von Hindernissen, die der Flexibilisierung im Wege stehen, besonders laut.

Die Ergebnisse basieren auf qualitativen Expertenund Expertinneninterviews. Sie zeigen, dass sich der Wandel erstens durch eine Ausdifferenzierung der Arbeitsverhältnisse auszeichnet und sich zweitens eine akzentuierte ethnische Unterschichtung des Arbeitsmarktes herausbildet. Drittens findet die Ausdifferenzierung ihr Abbild auf der regulativen Ebene. Die auf das Verhältnis zwischen in- und ausländischer Arbeit fokussierende Analyse führt viertens insofern zu einem erweiterten Regulationsbegriff, als sie nicht nur die Regulation der Konfliktlinie zwischen Kapital und Arbeit sondern auch diejenige zwischen Ethnien bzw. Nationalitäten thematisiert (= duales Regulationssystem). Die Reichweite des Regulationsansatzes schliesslich wird insofern kritisch beleuchtet, als die Koexistenz fordistischer und nachfordistischer Arbeitsverhältnisse nachgewiesen werden kann.

\section{Résumé: Les conditions de travail durant la transition du fordisme au postfordisme, ou: Pourquoi de plus en plus d'étrangers se comportant comme des étrangers sont-ils employés aujourd'hui dans l'hôtellerie et la gastronomie suisses?}

Il est question, au regard de la théorie de la régulation, de la mutation du rapport salarial (autochtone et étranger) et de sa régulation en tant qu'expression et image d'une accumulation flexible. Nous jetons ainsi un regard critique sur la controverse relative au marché du travail, orientée vers la concurrence et l'innovation, en mettant l'accent sur les gagnants de la modernisation et sur les possibles perdants de la flexibilisation.
Nos propos se fondent sur l'exemple du secteur de l'hôtellerie et de la gastronomie, secteur qui occupe un rôle pionnier en ce qui concerne la flexibilisation du marché du travail. L'exemple de la Suisse constitue une «voie de développement national» particulièrement mise à l'épreuve par les nouvelles conditions de concurrence. L'appel à l'abolition des obstacles à la flexibilisation devient de ce fait particulièrement pressant.

Les résultats sont basés sur des entretiens qualitatifs avec des experts. Ils montrent, en premier lieu, que le changement se caractérise par une différenciation des conditions de travail et, en second lieu, qu'un clivage ethnique du marché du travail s'accentue. Nous observons ensuite que cette différentiation trouve sa correspondance au niveau de la nouvelle régulation. Puis nous constatons que l'analyse focalisée sur la relation entre travail autochtone et étranger conduit à une compréhension plus large du concept de régulation, puisqu'elle thématise la régulation non seulement des conflits entre capital et travail, mais aussi de ceux entre ethnies, respectivement nationalités (système de régulation dual). Un regard critique est enfin porté sur la validité de la thèse de la régulation, la coexistence de conditions de travail fordiennes et post-fordiennes pouvant être démontrée.

Dr. Katrin Schneeberger, Mühlemattstrasse 37, CH3007 Berne. e-mail: katrin.schneeberger@gmx.ch

Prof. Dr. Paul Messerli, Department of Geography, Berne University, Hallerstrasse 12, CH-3012 Berne. e-mail:mep@giub.unibe.ch

Manuskripteingang/received/manuscrit entré le 28.5.2002

Annahme zum Druck/accepted for publication/accepté pour l'impression: 20.9.2002 